\title{
A call for abolition: The disavowal and displacement of race in critical security studies
}

Security Dialogue 202I, Vol. 52(S) 60-68 (C) The Author(s) 2021 (c) (i) $(8)$

Article reuse guidelines: sagepub.com/journals-permissions DOI: $10.1177 / 09670106211024413$ journals.sagepub.com/home/sdi

(SAGE

\author{
David Chandler \\ University of Westminster, UK
}

\author{
Farai Chipato 1 \\ University of Ottawa, Canada
}

\section{Introduction}

In 2020, Security Dialogue issued a call for interventions on race and racism in critical security studies, responding to a tumultuous year of global upheaval and academic controversy surrounding racial issues in contemporary society. In the call, the editors highlighted the lack of engagement with race in the field, requesting submissions that interrogate these issues and propose reparative framings to inform future research. Our response to this call seeks to raise some notes of caution, to indicate that the depth and nature of the problem require full acknowledgement prior to the consideration of what, if any, reparative work may be undertaken. We do not think that the call is problematic in its statement that 'the spectres of race and racism haunt the field of critical security studies, not just the broader discipline of International Relations' (Security Dialogue, 2020). However, we question the ability of the field to provide reparative perspectives that are adequate to the task of grappling with these spectres.

Since its beginnings, critical security studies has sought to move discussions of security away from traditional, state-centric perspectives, towards broader and deeper approaches, often focusing on the possibility of security as emancipation or interrogating its conceptual foundations. Studies emerged that focused on gender, securitization, new materialism, ontological security and many other issues, as well as race, as critical security scholars found new and diverse subjects to centre their research on. Recent ground-breaking work has highlighted how spectres of race within the canon of thought in international relations continue to shape disciplinary approaches and assumptions, with Meera Sabaratnam's (2020) and Olivia Rutazibwa's (2020) work being just two examples. Despite these interventions, issues of race and racism remain peripheral to the field, understood as an addition to the discussion rather than a foundational factor at the core of notions of security and the world they seek to secure. The question, then, is whether it is possible or desirable to disentangle critical security studies from its racial foundations, to salvage or redeem it, and, if so, how 
this might be possible. To answer this, we suggest that it is necessary to explore and address the problem that race poses for the discipline not just at the level of overtly discriminatory and hierarchical strategies of power and control but also at a deeper, ontological, level.

It is at this level that a consensus on the problem and the possibilities for reparation often breaks down. An illustration of this difficulty was provided by the recent controversy surrounding a critique of securitization studies, published in this journal, by Alison Howell and Melanie RichterMontpetit (2020; see also Wæver and Buzan, 2020). The difficulty was that of critiquing anti-Blackness without offending or bringing into question the 'critical' credentials of the scholars involved in developing and articulating a leading approach within critical security studies. The heated and fractious disagreements that followed publication of Howell and Richter-Montpetit's article indicate the sensitivities involved and the difficulties of clarifying and distinguishing a deeper - or ontological - understanding of the spectres of race and racism from a narrower - or more surface - critique of the normative standpoint or epistemological framing of the author(s).

It is this distinction that we wish to make in our intervention here. We believe that a focus on ontology can enable scholars in the discipline to negotiate the difficulties involved in attempting a cut between the past, the present and the future of critical security studies. In fact, we argue, the assumption that the 'spectres of race and racism' are behind us and that critical security studies can and should focus on the future of repair through openness and solidarist affirmation risks evading these tasks of clarification. Thus, for example, it may not be necessarily possible or even desirable to take the leap recommended by Olivia Rutazibwa (2016: 199) in her call for a scholarship capable of contributing 'to a radically different, anti- or non-racist [international relations] and everyday'. In this short intervention, we lay out an argument that suggests that true reparative work may not be possible within the current academic landscape. To do this, we first address the relationship between anti-Blackness and security and then consider the dangers of disavowal and disarticulation in calls for reparative work, concluding with our own call - inspired by our readings of work in the field of critical Black studies - that of abolition.

\section{Security in an anti-Black world}

Security Dialogue's call comes out of a wider move to include race in discussions of international relations, amid calls to 'decolonize' a discipline that has always been at the heart of colonial power structures (Sabaratnam, 2017). Yet, in order to understand what is at stake in this move to include race in a discipline that formerly seemed to ignore it, we must consider the relationship between Blackness and the world, the ontological condition that makes anti-Blackness inextricable from security. In short, we must realize that questions of race and racism have always been the ground that critical security studies stands on.

The idea that racism can be isolated and extracted from an academic discipline while its effects are therapeutically addressed is challenged by the weight of Afropessimist scholarship, critical Black feminist and anti-colonial thinking. The urge to 'decolonize' academia suggests that coloniality is a condition that can be uprooted within the university without addressing the broader antiBlack world that universities are in. Some prominent decolonial scholars have challengingly argued that 'decolonization is not a metaphor' (Tuck and Yang, 2012), and others have suggested the need for pluriversal approaches to security that allow for inclusion of a multitude of nonWestern ontologies (Escobar, 2018). However, even pluriversal approaches risk retaining parts of the edifice of modernity without addressing its anti-Black foundations, leaving open the possibility of 're-enchanting and pluralising [international relations]' (Rothe, 2019: 9), assuming that redemption and reparation is possible. The temporality at stake is that which seeks to salvage 'critique' through an imaginary telos of progress - learning the lessons and moving onwards, ever opening 
and exploring new avenues and new approaches - hence the appeal to an ethico-political 'openness' that the making of reparative politics is held to enable. This attempt to move 'beyond' the problem of 'the spectres of race and racism' is laudable but, we argue, misguided. It is precisely critical narratives of 'progress' that critical Black studies and Afropessimism seek to problematize (Ray et al., 2017).

Rather than considering anti-Blackness as an epiphenomenon of modernity, a glitch in our system that needs to be fixed, it may be understood as constitutive of a modern ontology (Wilderson, 2010). As Nahum Dimitri Chandler (2014: 130) states, 'there is no contemporary discourse that is free or independent of the itinerary of the concept of race'. The existence of Blackness is ontologically crucial in providing the boundaries of humanity, in creating the Outside, the Other, that is necessary to define the inside of modernity, civil society and human subjectivity (Warren, 2018). As Saidiya Hartman (2017: 33) argues, 'the texture of freedom is laden with the vestiges of slavery, and abstract equality is utterly enmeshed in the narrative of black subjection'. Thus, for Afropessimists, it is not merely the contemporary order of humanity that is enmeshed with antiBlackness, but also the struggles for emancipation by those within that order. This does not mean that there is no oppression among those who are recognized as human, but that their struggles for freedom within this space are of a different order from that of Black people, as the space of these internal conflicts is constituted by anti-Blackness. In order for there to be security for humanity, in order for the liberal subject, civil society and a world of progress to function, Blackness must remain outside, as the counterpoint to the telos of modernity.

This throws into question calls for inclusion, for justice and for reparation, as well as the ability for the global system to be accountable for the suffering and death of Black people. If anti-Blackness is a structural necessity for the system to exist, then there can be no justice, no end to violence against Black people if the current system persists. The drive to include Black people in civil society, to promote multiculturalism, diversity and inclusion, leaves untouched the ontological condition of Blackness, which is required to maintain the borders of humanity. The radical force of Black liberation movements was blunted by the drive to assimilate them, to include Black people in the political sphere, to recognize and celebrate their 'ethnic identity', without addressing the fundamental condition of Blackness. In the USA, anti-Black violence remains a necessity to maintain security, despite the inclusion of Black people at all levels of government. Inclusivity does not ameliorate the problem; it merely obfuscates it. As Frank Wilderson (2010: 103) argues, 'few characters aestheticize White supremacy more effectively and persuasively than a Black male cop'. American governance is not 'haunted' by race, it is constituted through race.

Thus the line between humanity and Blackness is not shattered through the inclusion of some Black people in the space of civil society; rather, it is reinforced. In South Africa, the Black inhabitants of townships continue to endure state violence and poverty despite the formal end of apartheid. Black activists now protest against their government by 'black boers' (settlers), those who have crossed the line into humanity only to fortify it against their former compatriots (Madlingozi, 2017). This is because, as Tsepho Madlingozi (2017: 14) argues, 'the main edifice of the ontological structure of colonial-apartheid . . remains in place'. In order to ensure the security of settler society, those few who have been inducted into it must maintain the violence of the anti-Black order that is said to be overturned.

Security, then, is sustained through anti-Blackness, for if the abject non-subject of the Black experience does not exist as a point of contrast, then humanity cannot be safe. The subjectivity of the (non-Black) human is imperilled, without the safety of anti-Black violence that ensures its ontological integrity. If this is the case, then we must re-read the call to bring considerations of race and racism into critical security studies and question the feasibility of achieving an ethico-political reparation in a discipline that relies on the structure of an anti-Black system. 


\section{Disavowal: 'Spectres' and 'foundations'}

Having grasped the nature of the relationship between anti-Blackness and security, let us reflect on the assumptions underpinning the desire to rejuvenate the criticality of the field through reparative approaches to race. We see a potential problem with the argument that the recent important work by the scholars like Sabaratnam (2020) and Rutazibwa (2020) on security's racial underpinnings has cleared the ground for a project of accounting and reparation while maintaining existing academic fields recognizably intact. Indeed, recent work on race in security and global politics has highlighted many potential issues, demonstrating the substantial challenge facing reparative projects. As Anna Agathangelou and Kyle Killian (2016) demonstrate, considered ontologically, coloniality is much more than a set of space- and time-specific policy practices, but rather a world-making (and worlds-destroying) practice through which our understanding of global space and time is constructed (see also Grovogui, 2014; Jackson, 2020; Silva, 2007). Moreover, critical sociological accounts of security and international relations argue that the imposition of racial difference is intimately tied to colonial and settler-colonial power as a technique of control and regulation that naturalizes and reproduces differential powers and capacities (e.g. Henderson, 2013; Nisancioglu, 2020). Race and white supremacy are thus inextricable from hegemonic regimes of power and imposition, at the heart of the discipline, despite the abstract categories of liberal political theory that structurally operate to occlude the centrality of race to contemporary political divisions and understandings. As Gurminder Bhambra argues (2017), the location of race is often displaced - to claims to identity and difference, seen to be racial - while white-coded framings of 'sovereignty' and 'class' obscure their racialized grounding.

This important work on the nature of race and racism in security studies shows that the problem is not so much one of a lack of incorporation of questions of race and racism, but rather that of a thoroughgoing saturation in issues of race. This ontological saturation implies that there can be no definitive temporal break between the colonial past and a postcolonial present. Coloniality remains in the present not only in residue, but rather as an 'ongoing and quotidian atrocity', inevitably problematizing attempts at reparation (see discussion in Sharpe, 2016: 20). We are thereby fully sympathetic to Howell and Richter-Montpetit's (2019) understanding that 'questions of race and racism' cannot be disentangled from critical security studies or, for that matter, the broader field of international relations. As Jared Sexton (2008: 22) powerfully notes, any attempt to separate 'questions of race and racism' from systems, structures and institutions of power already risks disavowing the centrality of race and its reduction to a secondary or contingent aspect.

\section{Displacement: 'Reparation' and 'anti- or non-racist international relations'}

We have seen above that disavowal operates on the basis of stipulating that the problem of race and racism is one that can be located in the past, intimating that the problem is a difficult one of 'spectres' or legacies that must and can be overcome. This is possible because the assumption is that questions of race are somehow separable from the field of critical security studies itself, rather than constitutive of it. The successful accomplishment of disavowal, then, enables a focus upon how critical security studies might move forward. This leap, we argue, is a displacement that then puts questions of the future of critical security studies at the forefront of concern. The displacement accomplishes the inversing of the problematic: critical security studies is now the solution rather than the problem. The precondition for reparative work is the disavowal that race and racism are inextricably entangled with critical security studies. The shift of displacement is the move to reparation, the imaginary of an anti- or non-racist critical security studies. 
The problem with this move of displacement is that the ethico-political stance of reparation is necessarily an affirmative one. As Eve Kosofsky Sedgwick (2003: 150-151) suggests, it is through this displacement that we can learn from the 'ways selves and communities succeed in extracting sustenance from the objects of a culture - even of a culture whose avowed desire has often been not to sustain them'. As Tiffany Lethabo King powerfully argues, while it is the case that reading 'for what is generative and provides openings' (King, 2019: 230n74) is vital for coalition and collaboration, reparative work advocated in LGBT and queer theory presupposes the positionality of a shared humanist sexual subject position. As Fred Moten (2018: 11-12) notes in his essay on race and the work of Levinas, the reparative stance of being 'open to the world' or 'available to the world' can only work as a critical project for those for whom the world is accessible in these ways. For those structurally excluded from this political ontology of the subject, this openness would be critical

only insofar as relationality is understood to be an expression of power, structured by the givenness of a transcendental subjectivity that the black cannot have but by which the black can be had; a structural position that he or she cannot take but by which he or she can be taken. (Moten, 2018: 204)

Any project of reparative work for generative ethico-political openings would have to be undertaken after the abolition or dismantling of critical security studies, not as a substitute for this, displacing the problem to that of the repair of the disciplinary field.

Reparative work proffered from within a system where race is not merely the 'oil' in the engine but the engine itself offers little hope of real change. How can critical security studies offer a space for a new antiracist political ethics, from within the wider 'prison of colonial modernity' (Blaney and Tickner, 2017)? Surely, if reparative work is to be undertaken, it should be carried out on the terms of those who are wronged, rather than on the grounds of the perpetrator of the offence. If critical security studies exists on the ground of the 'human', as a science of the humanity from which Blackness has always been excluded, then it cannot ameliorate the oppression that was required to clear that ground (Wynter, 2003). Instead, we might follow Alexander Weheliye (2014: 137 ) in arguing that humanity, the idea of the 'human', can only be overhauled from without, transformed by those who, he argues, 'live behind the veil of the permanent state of exception'. Thus, we might argue that reparation ultimately leads us back to subjection (see Coulthard, 2007: 453).

'Questions of race and racism' are not the spectre haunting critical security studies, they are its life blood, its arteries and the muscles that power it. Critical security studies can have no reparative access to 'questions of race and racism' no matter how hard or how genuinely it tries. 'Questions of race and racism' are what enable the cuts and binaries, the world, the subjects, the concerns, the practices, the methods, the understandings of critical security studies. Critical. Security. Studies. What is it about these three words, singularly, together, in whatever order, that could make anyone think, in today's world, there was a way beyond their imbrications in 'questions of race and racism'? Critical of what? On what grounds? Security of what? On what grounds? Study of what? On what grounds? Answer: the grounds of anti-Blackness or 'questions of race and racism'.

\section{Critical}

Being critical necessitates having a standpoint, being a subject in relation. For the white world of modernity, critical standpoints enabled the overturning of the relation, freeing the subject from its oppression, alienation or exploitation. As Frank B. Wilderson (2010:37) notes, these 'grammars of suffering' are grounded upon anti-Blackness, grounded upon the construction of the human as an abstract, autonomous, interest-bearing, rational subject. Wilderson argues that the exclusion of 
Blackness from humanity was required as a counterpart, an outside that allowed for the construction of the modern human subject. Thus, critique, in the sense of striving for emancipation under the conditions of modernity, is ontologically grounded in anti-Blackness. For 'critique', then, 'questions of race and racism' are problems of management and damage limitation, problems of experience not problems of ontology. Addressing 'questions of race and racism' is the form that governance takes, the practice of grounding this governance itself. Critique is what puts antiBlackness to work in its ceaseless desire to reproduce itself, to improve, to better, to be more adaptive, to be more inclusive - ever changing, ever learning, ever transforming. Therefore, the mere inclusion of questions of race and racism, which maintain the ontological structure of anti-Blackness, must perpetuate an anti-Black world. Critique is the endless search for the emancipation of the human, the quest for the realization of the full potential of an anti-Black world. The flight of critique today can be rewritten as the perpetual denial of and war on Blackness, that which enables and 'makes invisible' its grounds of violence.

\section{Security}

Today we know that 'security' is just another word for extinction and genocide. Every discourse of securing implies that there is a ground to be secured, a 'home', a way of being that is threatened or that requires saving, sustaining and being located within a temporality and spatiality. It is precisely this security that is denied in an anti-Black world. As Saidiya Hartman argues, only recognized subjects have something to secure; for others, 'home' is an impossibility: 'We stay there, but we don't live there' (Hartman, 2007: 87). As has already been stated, every ground of this discourse is built on anti-Blackness. However inclusive the space that is secured, it will always require a boundary, a delineation of an outside that is inhabited by those who cannot be full human subjects. Every cut between that to be secured and that which can be left or seen as expendable or without value necessarily depends on 'questions of race and racism'.

\section{Studies}

It is perhaps the most harmless of the 'three little words', but 'studies' contains all we need to know of hierarchies and cuts - of the 'human' from the world, of the knowing subject from the object to be known and 'studied'. For critical security studies, the study itself is already the violence that enables the violence of 'sustained discrimination', the violence that we are told is both 'invisible and acceptable' (Security Dialogue, 2020). Study is a practice of the world of the subject, the world of critical security, the world of anti-Blackness. Yes, 'study' as a concept could be reclaimed for a world beyond anti-Blackness, but this would not be the 'study' that demarcates one 'field' from another. Fred Moten and Stefano Harney (2013: 118), for example, talk of study as the disruption of the grounds that would enable the study of 'studies'. This form of study is the refusal of the settled order of academia, the flight from the institutional demands of disciplinarity, the embrace of dissonance instead of clarity. Study is the reason for the abolition of critical security studies, the reason why you would leave the world of policy and academia, not why you would seek to expand it. Study is the work and the interaction and the care that is in the world. 'Study' is not the product of critical security studies; it can only be what critical security studies sets itself against, to carve itself out of, to separate itself from. Critical security studies can no more undertake this form of study than it can engage with 'questions of race and racism'. 


\section{Conclusion}

What, then, does it mean for the field if the grounds of critical security studies are the grounds of anti-Blackness? Not 'just' the 'foundations' but the grounds that enable the divide between the 'foundations' and the 'novel and ethico-politically committed ways' (Security Dialogue, 2020) to be discovered in the present or in the future. The grounds that enable the authorized critical security studies subject to articulate the desire for 'reparation' and for 'ethico-politically committed ways' to enable the continuation of a project that has no ground of its own. The investigation of antiBlackness we have presented suggests that, at an ontological level, only questions of race and racism exist, and critical security studies is a form of their expression.

To reiterate our position: we have sought to make two fairly straightforward points. First, on the questions of race and racism, there is a possibility that no reparative ethico-political openings can be made from within the subject position of critical security studies. To pursue this reparative project would require the reinstatement of the series of closures and exclusions that constitute the hegemonic imaginaries of the discipline. Second, critical security scholars should consider whether in fact there can be any repair-ation or repair of critical security studies. We build on the important existing critiques of race in security studies to argue that to take seriously the question of race and racism would clarify the difficulty, perhaps even the impossibility, of any reparation. Indeed, perhaps the only possibility of a truly novel and ethical future lies in abolition of the entire intellectual, institutional, ontological edifice that critical security studies is embedded in. As Harney and Moten (2013: 152) argue, for the field of critical or radical thought more generally, 'what it is that is supposed to be repaired is irreparable. It cannot be repaired. The only thing we can do is tear this shit down completely and build something new.'

\section{Funding}

The author(s) received no financial support for the research, authorship, and/or publication of this article.

\section{ORCID iD}

Farai Chipato (D) https://orcid.org/0000-0001-9122-9764

\section{References}

Agathangelou AA and Killian KD (2016) International relations as a vulnerable space: A conversation with Fanon and Hartman about temporality and violence. In: Agathangelou AA and Killian KD (eds) Time, Temporality and Violence in International Relations: (De)fatalizing the Present, Forging Radical Alternatives. Abingdon: Routledge, 23-42.

Bhambra GK (2017) Brexit, Trump, and 'methodological whiteness': On the misrecognition of race and class. British Journal of Sociology 68(S1): S214-S232.

Blaney DL and Tickner AB (2017) International relations in the prison of colonial modernity. International Relations 31(1): 71-75.

Chandler ND (2014) X: The Problem of the Negro as a Problem for Thought. New York: Fordham University Press.

Coulthard GS (2007) Subjects of empire: Indigenous peoples and the 'politics of recognition' in Canada. Contemporary Political Theory 6(4): 437-460.

Da Silva DF (2007) Towards a Global Idea of Race. Minneapolis, MN: University of Minnesota Press.

Escobar A (2018) Designs for the Pluriverse: Radical Interdependence, Autonomy, and the Making of Worlds. Durham, NC: Duke University Press.

Grovogui SN (2014) Beyond Eurocentrism and Anarchy: Memories of International Order and Institutions. Basingstoke: Palgrave.

Harney S and Moten F (2013) The Undercommons: Fugitive Planning \& Black Study. New York: Autonomedia. 
Hartman S (2007) Lose Your Mother: A Journey Along the Atlantic Slave Trade. New York: Farrar, Straus \& Giroux.

Hartman S (2017) The burdened individuality of freedom. In: Wilderson FB, Hartman S, Martinot S, Sexton J and Spillers HJ, Afro-Pessimism: An Introduction. Minneapolis, MN: Racked \& Dispatched, 31-48.

Henderson EA (2013) Hidden in plain sight: Racism in international relations theory. Cambridge Review of International Affairs 26(1): 71-92.

Howell A and Richter-Montpetit M (2019) Racism in Foucauldian security studies: Biopolitics, liberal war, and the whitewashing of colonial and racial violence. International Political Sociology 13(1): 2-19.

Howell A and Richter-Montpetit M (2020) Is securitization theory racist? Civilizationism, methodological whiteness, and antiblack thought in the Copenhagen School. Security Dialogue 51(1): 3-22.

Jackson ZI (2020) Becoming Human: Matter and Meaning in an Antiblack World. New York: New York University Press.

King TL (2019) The Black Shoals: Offshore Formations of Black and Native Studies. Durham, NC: Duke University Press.

Madlingozi T (2017) Social justice in a time of neo-apartheid constitutionalism: Critiquing the anti-black economy of recognition, incorporation and distribution. Stellenbosch Law Review 28(1): 123-147.

Moten F (2018) The Universal Machine (Consent Not to Be a Single Being). Durham, NC: Duke University Press.

Nisancioglu K (2020) Racial sovereignty. European Journal of International Relations 26(1_Suppl.): S39S63.

Ray VE, Randolph A, Underhill M and Luke D (2017) Critical race theory, Afro-pessimism, and racial progress narratives. Sociology of Race and Ethnicity 3(2): 147-158.

Rothe D (2020) Governing the End Times? Planet politics and the secular eschatology of the Anthropocene. Millennium: Journal of International Studies 48(2): 143-164.

Rutazibwa O (2016) From the everyday to IR: In defence of the strategic use of the R-word. Postcolonial Studies 19(2): 191-200.

Rutazibwa O (2020) Hidden in plain sight: Coloniality, capitalism and race/ism as far as the eye can see. Millennium: Journal of International Studies 48(2): 221-241.

Sabaratnam M (2017) Decolonising International Intervention: International Statebuilding in Mozambique. New York: Rowland \& Littlefield.

Sabaratnam M (2020) Is IR theory white? Racialised subject-positioning in three canonical texts. Millennium: Journal of International Studies. Epub ahead of print 25 November 2020. DOI: 10.1177/0305829820971687.

Security Dialogue (2020) Call for interventions: Race and racism in critical security studies - Reparative possibilities for a field of study and practice. Available at: https://journals.sagepub.com/pb-assets/cmscontent/SDI/Call\%20for\%20interventions\%20Race\%20and\%20Racism-1587461824600.pdf (accessed 26 April 2021).

Sedgwick EK (2003) Paranoid reading and reparative reading, or, You're so paranoid, you probably think this introduction is about you. In: Sedgwick EK, Touching Feeling: Affect, Pedagogy, Performativity. Durham, NC: Duke University Press, 123-151.

Sexton J (2008) Amalgamation Schemes: Antiblackness and the Critique of Multiracialism. Minneapolis, MN: University of Minnesota Press.

Sharpe C (2016) In the Wake: On Blackness and Being. Durham, NC: Duke University Press.

Tuck E and Yang WK (2012) Decolonization is not a metaphor. Decolonization: Indigeneity, Education and Society 1(1): 1-40.

Wæver O and Buzan B (2020) Racism and responsibility - The critical limits of deepfake methodology in security studies: A reply to Howell and Richter-Montpetit. Security Dialogue 51(4): 386-394.

Warren CL (2018) Ontological Terror: Blackness, Nihilism, and Emancipation. Durham, NC: Duke University Press.

Weheliye AG (2014) Habeas Viscus: Racializing Assemblages, Biopolitics, and Black Feminist Theories of the Human. Durham, NC: Duke University Press. 
Wilderson FB, III (2010) Red, White and Black: Cinema and the Structure of U.S. Antagonisms. Durham, NC: Duke University Press.

Wynter S (2003) Unsettling the coloniality of being/power/truth/freedom: Towards the human, after man, its overrepresentation - An argument. CR: The New Centennial Review 3(3): 257-336.

David Chandler is Professor of International Relations, University of Westminster, London, UK. He edits the journal Anthropocenes - Human, Inhuman, Posthuman. His latest books include Anthropocene Islands: Entangled Worlds (with Jonathan Pugh, 2021) and Becoming Indigenous: Governing Imaginaries in the Anthropocene (with Julian Reid, 2019).

Farai Chipato is Alex Trebek Postdoctoral Fellow at the Centre for International Policy Studies, University of Ottawa, Canada. He is Reviews Editor at the journal Review of African Political Economy. His work addresses democracy promotion, civil society and race in International Relations. 